\title{
Study of Embryotoxicity of Mentha piperita L. During Organogenesis in Balb/c Mice
}

\author{
Estudio de la Embriotoxicidad de Mentha piperita L. Durante la Organogénesis en Ratones Balb/c
}

"Mohammad Jafar Golalipour; "**Soraya Ghafari; ${ }^{* * *}$ Alireza Maleki; ${ }^{* * * *}$ Mossa Kiani; ${ }^{* *}$ Ebrahim Asadi \& **** Mirmerhdad Farsi

GOLALIPOUR, M. J.; GHAFARI, S.; MALEKI, A.; KIANI, M.; ASADI, E. \& FARSI, M. Study of embryotoxicity of Mentha piperita L. during organogenesis in Balb/c mice. Int. J. Morphol., 29(3):862-867, 2011.

SUMMARY: Mentha piperita (Labiatae), commonly known as peppermint is a native Iranian herb which is used in folk medicine for various purposes. This study was carried out to reveal the teratogenic effect of Mentha piperita on mice fetuses. In this experimental study, pregnant Balb/c mice divided to four groups. Case group received 600 (treatment I) and 1200 (treatment II) mg/kg/day the hydroalcoholic extract of Mentha piperita during 6-15 of gestational days and one control group received normal saline during GD6-GD15 by gavages and other control group did not receive any matter during 6-15 of gestational days. Mice sacrificed at GD18 and embryos were collected. Macroscopic observation was done by stereomicroscope. 20 fetuses of each group were stained by Alizarin red-S and Alcian blue staining method. The Mean weight of fetuses decreased in treatment groups rather than control $(\mathrm{P}<0.05)$ but CRL there was no significant difference between treatments and controls groups. In the treatment I (600 mg/kg/day) and treatment II (1200 mg/kg/day), normal saline and control group, no gross congenital malformations were observed in fetuses. Treated fetuses also had no delayed bone ossification as determined by Alizarin red-S and Alcian blue staining method. This study showed that the hydroalcoholic extract of Mentha piperita (600 and $1200 \mathrm{mg} /$ $\mathrm{kg}$ /day) has no teratogenic effect in mice fetuses if used continuously during embryonic period.

KEY WORDS: Mentha piperita; Teratogen; Bone ossification; Developmental toxicity; Mice.

\section{INTRODUCTION}

More than $80 \%$ of the people in the world population currently rely on traditional medicines and most of these therapies involve the use of plant extracts (Zhang, 2002). Recent reports indicate a wide use of medicinal herbs by pregnant women (Hepner et al., 2002).

Mentha piperita is a herb, which is commonly, used in folk medicine, in Iran, turkey, India, the Middle East, Europe and Canada for flatulent colic, appetite, to relieve abdominal pain, fever, nausea and vomiting and digestion (Zargari, 1996; Westfall, 2004; Starbuck, 2001).

Also $M$. piperita is used for preventing vomiting and morning sickness in pregnant women (Westfall). M. piperita contains volatile oil, menthol, menthon, methofman, and limonene (Adkogan et al., 2004a; Baser, 1993).

The chemical components of leave extract and oil of M. piperita vary with plant maturity, geographical region and processing conditions (Ruiz Del Castillo et al., 2003; Xu et al., 2003).

Previous studies have shown antiviral, antibacterial and anti fungal effects of M. piperita (Minami et al., 2003; Schuhmacher et al., 2003; Choi et al., 2003; Azuma et al., 2003; Duarte et al., 2005; Tampieri et al., 2005).

Also, Inoue et al. (2002) and Satsu et al. (2004) reported anti allergic effects of this herb. Furthermore, previous studies have been shown anti-inflammatory, analgesic and antispasmodic effects of M. piperita (Atta \& Alkofahi, 1998; Göbel et al., 1995, 1996; Juergens et al., 1998; Asao et al., 2003; Hiki et al., 2003; Micklefield et al., 2003). Also Tate et al. (1997) reported anti nausea effect of this herb.

Some studies reported that the extract of M. piperita reduce symptoms in dyspepsia (Madisch et al., 2001; Rösch et al., 2002) and IBS patients (Kline et al., 2001).

\footnotetext{
*Professor, Gorgan Congenital Malformations Center, Department of Anatomical Sciences, Golestan University of Medical Sciences, Gorgan, Iran.

**Department of Anatomical sciences, Golestan University of Medical Sciences, Gorgan, Iran.

***Faculty of Medicine, Golestan University of Medical Sciences, Gorgan, Iran.

****Assistant Professor, Department of Anatomical Sciences, Babol University of Medical Sciences, Babol, Iran.
} 
Furthermore, a study reported the histophatological effect of Mentha piperita on white matter of cerebellum and proximal convoluted tubules in animal model (Thorup et al., 1983; Spindler \& Madsen, 1992). It was reported that the oil of Mentha piperita has a genotoxic effect on human lymphocytes (Lazutka et al., 2001).

Recent researches has shown that spearmint tea has antiandrogenic properties in both animals and females (Adkogan et al., 2007; Güney et al., 2006) and anti spermatogenic activity in rodents (Adkogan et al., 2004; Sampaio, 2004).

On the other hand some researches showed the chemoprotective, antimutagenic and anti carcinogenic effects of M. piperita (Samarth et al., 2006; Samarth \& Kumar, 2003; Samman et al., 1998). In Regard to the use of Mentha piperita for preventing vomiting and morning sickness in pregnant women there is a lack of studies about teratogenic effects of Mentha piperita. This investigation was carried out to reveal the teratogenic effect of M. piperita on Balb/c mice fetuses.

\section{MATERIAL AND METHOD}

Time and setting. The study was performed in 2008 at the Faculty of Medicine, Gorgan University of Medical Sciences. Approval for this study was gained from the Animal Care and Ethics Committee of the Gorgan University of Medical Sciences.

Materials. Plant material. Mentha piperita leaves were collected from cultivated plant, from suburb of Gorgan, Northern Iran.

Methods. Preparation of plant extract. The aerial parts of Mentha piperita were reduced to small pieces, dried in a circulating air stove and powdered in a grinder. The powdered material was then macerated using a hydroalcoholic $\left(60^{\circ}\right)$ solvent for 48 hours. The ethanol was removed by vacuum distillation and the resulting residue was filtered and concentrated at $40 \mathrm{C}^{\circ}$ to make a jelly-like material. In addition to thin layer chromatography and purity tests (foreign matter, total ash, acid insoluble ash and water insoluble ash) for qualification analysis, monosaccharide-linked another reagent assay (spectrophotometry) have been carried out to determine the concentration of polysaccharides in Mentha piperita leaves for standardization of the extract.

At the time of administration, the prepared powder of the extract was solved by the saline and the mice were treated with the solution.
The animals used in this study were experimental, 28-30 gram weight, and 7-8 week old virgin female and mature male Balb/c mice. The males were part of the animal house breeding stock with confirmed mating experience. Dry food pellets and water were provided ad libitum with animal house conditions maintained at $20-22^{\circ} \mathrm{C}, 65-68 \%$ relative humidity, and a $12 \mathrm{~h}: 12 \mathrm{~h}$ photoperiod (lights on 0700-1900h). Two females were caged with a male of the same strain overnight. The presence of vaginal plug the next (following) morning confirmed that mating had taken place and was designated as day zero of pregnancy (Gestation Day 0 : GD 0 ). Females that did not mate within 2 estrus cycles were excluded from the study.

Pregnant mice were randomly divided into the two experimental groups $(600 \mathrm{mg} / \mathrm{kg} / \mathrm{day}$ and $1200 \mathrm{mg} / \mathrm{kg} /$ day of Mentha piperita extract) and the two control groups. 12 mice in the two experimental groups received $600 \mathrm{mg} /$ $\mathrm{kg} / \mathrm{day}$ and $1200 \mathrm{mg} / \mathrm{kg} / \mathrm{day}$ orally of Mentha piperita extract respectively. One control group received normal saline orally, from GD 6 to GD 15, by oral intubation. The other control group did not receive normal saline. On GD 18 the pregnant mice were sacrificed under chloroform anesthesia and uterus was opened and umbilical cord cut close to the fetus; each fetus and placenta were then weighed. Each fetus was assigned a number according to its position in the uterine horn, starting with number one at the ovarian end of the left uterine horn. Fetuses were assessed as either alive or dead and any resorption was noted. All live fetuses were measured crown-rump length (CRL), Bi-parietal diameter (BPD) and were examined externally for 'Qlformations or deviations from normal growth as described. Also, each of the fetuses was weighed by sensitive electronic measurement serrations PT 210 German and observed for gross malformations by stereo research microscope, Blue Light US. Fetuses were eviscerated and the skin removed to facilitate stain penetration. Skeletal staining of fetuses was performed by the Alcian Blue- Alizarin Red S method. Differences in body weight, bi-parietal diameter (BPD) and crown rump length (CRL) between controls and treatment groups were analyzed using a one-way ANOVA. A value of $\mathrm{P}<0.05$ was considered to indicate a significant difference between groups.

\section{RESULTS}

During the whole experiment, no maternal deaths and behavioral changes were recorded in any group. The treated females consumed as much food and water as the controls and gained comparable weight. 
GOLALIPOUR, M. J.; GHAFARI, S.; MALEKI, A.; KIANI, M.; ASADI, E. \& FARSI, M. Study of embryotoxicity of Mentha piperita L. during organogenesis in Balb/c mice. Int. J. Morphol., 29(3):862-867, 2011.

Table I. Number of live, absorbed fetuses, BPD, CRL, weight of fetuses in controls and treatments. *p<0.05 compared to controls.

\begin{tabular}{lccccc}
\hline Groups & Live Fetuses (n) & Absorbed & BPD (mm) & CRL (mm) & Weight (gr) \\
& & Fet uses (n) & & \\
\hline Control & 54 & 2 & $7.25 \pm 0.02$ & $22.96 \pm 0.38$ & $1.43 \pm 0.61$ \\
Control (Normal Saline) & 38 & 3 & $7.20 \pm 0.04$ & $22.85 \pm 0.22$ & $1.41 \pm 0.02$ \\
Treatment I (6oo mg/kg Mentha) & 45 & 6 & $7.15 \pm 0.12$ & $22.38 \pm 0.22$ & $1.29 \pm 0.02^{*}$ \\
Treatment II (1200 mg/kg Mentha) & 52 & 1 & $7.05 \pm 0.05$ & $22.03 \pm 0.16$ & $1.37 \pm 0.02^{*}$ \\
\hline
\end{tabular}

There were no signs of maternal toxicity due to Mentha piperita treatment. No signs of toxicity were noted in any of the animals. All pregnant animals appeared healthy at sacrifice. The weight of fetuses in treatment I (1.29 \pm 0.02$)$ and treatment II $(1.37 \pm 0.02)$ were lower than controls $(\mathrm{p}<0.05)$ (Table 1). Also BPD in the treatment I group $(7.15 \pm 0.12)$ and treatment II group $(7.05 \pm 0.05)$ was not significantly lower than the control $(7.25 \pm 0.02)$ groups (Table 1). Crown rump length in treatment and controls was similar.

Implantation and number of fetuses in the left horn $(55 \%)$ of uterine of the treatment group was higher than the right horn $(45 \%)$. While in the control group this percent was similar, $48 \%$ in the right and $52 \%$ in the left uterine horn. Major congenital malformations in fetuses were not found in treatment and control groups. Alizarin red S and Alcian blue staining did not show skeletal malformations and delayed bone ossification in the treated groups as comparing with control groups.

\section{DISCUSSION}

The findings of this developmental toxicity study showed that the Mentha piperita extract did not cause any major birth defects and delayed bone ossification in fetuses if used continuously during the embryonic period. There are very rare studies on the effect of Mentha piperita. Inoue study in Turkey showed that the M. piperita has a cytotoxic effect on rats (Inoue et al., 2001). Romero-Jiménez \& Campos-Sánchez (2005) reported that $M$. piperita oil has a cytotoxic effect and it induced the changes in chromatids chromosomes.

Furthermore, Lazutka et al. reported that $M$. piperita oil according to Smart method has a cytotoxic effect.

Gordon et al. (1987) reported that cytotoxic effect of Mentha piperita can be related to high level of pulegone which is a toxic substance or menthol.
Furthermore in a study, Akdogan et al. (2004b) showed that $M$. piperita decreased testosterone level and increased LH, FSH concentration in male rats. Also, he reported that this herb has effect on hypophyseal-testis hormonal axis causing alterations in germinal layer of seminiferous tubules in adult male rats thus Akdogan et al. concluded that $M$. piperita has antispermatogenic effect in rats.

In the literature we did not find any article about teratogenic effect of this plant. In our study we did not observe any birth defect or bony deletion in fetuses treated with Mentha piperita extract. Morphologic cytotoxic and hormonal alterations of this herb may be due in intracellular or DAN of cells. Also the different effects of M. piperita in different studies can be due to various chemical components of leave or oil extract of $M$. piperita which depend on plant maturity, species, geographical region and processing conditions (Ruiz del Castillo et al.; Xu et al.)

In this study, the fetuses of the treatment group had decreasing weight.

The decreasing weight of fetus in treated experimental groups may be due to the blocking of cell growth which may be due to genotoxic effect of this herb. Also the decreasing weight of fetuses in treated experimental groups can be due to reabsorbing of extra cellular liquid in the fetus. because extra cellular liquid in the fetus makes up the main part of weight and volume of fetuses. This mechanism was explained in previous studies which reported that saffron or crocin with reabsorbing of extra cellular liquid in the fetus causes decreasing weight in fetuses (Golalipour et al., 2008; Garcia-Olmo et al., 1999).

The growth of the fetus during intrauterine life is reflected in the weight at birth. Fetal growth is largely determined by the availability of nutrients from the mother, as well as placental capacity to supply these nutrients in sufficient quantities to the fetus. Of course there is evidence that both placental volume and the rate of placental growth may influence fetal size. Also the decreasing of weight of fetuses can be due to blocker effect on cell growth. 
This study showed that Mentha piperita extract has no teratogenic effect in mice fetus if it is used continuously during embryonic period, although this herb caused decreasing weight of fetuses. Therefore, regarding our results we suggest that pregnant women avoid high consumption of M. piperita during the organogenesis period.

Further study is needed to determine the exact mechanisms of decreasing fetus weight due to Mentha piperita consumption in organogenesis period.

\section{ACKNOWLEDGMENTS}

The authors appreciate the Department of Research Gorgan University of Medical Sciences for their financial support.

GOLALIPOUR, M. J.; GHAFARI, S.; MALEKI, A.; KIANI, M.; ASADI, E. \& FARSI, M. Estudio de la embriotoxicidad de Mentha piperita L. durante la organogénesis en ratones Balb/c.Int. J. Morphol., 29(3):862-867, 2011.

RESUMEN: Mentha piperita (Labiatae), comúnmente conocida como menta, es una hierba nativa de Irán, que se utiliza en la medicina tradicional para diversos fines. Este estudio fue realizado para descubrir el efecto teratogénico de la Mentha piperita en fetos de ratones. Los ratones Balb/c preñadas fueron divididas en cuatro grupos. Los grupos recibieron 600 (tratamiento I) y 1200 (tratamiento II) mg/kg/día del extracto hidroalcohólico de Mentha piperita durante los días 6-15 de gestación (DG), mientras que un grupo control recibió solución salina normal durante los DG 6-15 vía oral y otro grupo control sano no recibió substancia durante los DG 6-15. Los ratones fueron sacrificados el DG 18, recolectando los fetos. Se realizó la observación macroscópica mediante un estereomicroscopio. 20 fetos de cada grupo se tiñeron por el método de rojo de alizarina-S y azul de Alcián. La media de peso de los fetos disminuyó más en los grupos de tratamientos que los controles ( $\mathrm{p}<0,05)$, pero CRL no presentó diferencias significativas entre los tratamientos y los grupos control. En los fetos del grupos tratamiento I (600 mg/kg/día), tratamiento II (1200 mg/kg/día), solución salina normal y control no se observó ninguna malformación congénita grave. Los fetos tratados tampoco tuvieron osificación ósea retrasada según lo determinado por el método de rojo de alizarina-S y azul de Alcián. Este estudio mostró que el extracto hidroalcohólico de Mentha piperita (600 y $1200 \mathrm{mg} / \mathrm{kg} /$ día) no tiene efectos teratogénicos en fetos de ratones al ser utilizado continuamente durante el período embrionario.

\section{PALABRAS CLAVE: Mentha piperita; Teratógenos; Osificación ósea; Toxicidad para el desarrollo; Ratones.}

\section{REFERENCES}

Akdogan, M.; Gultekin, F. \& Yontem, M. Effect of Mentha piperita (Labiatae) and Mentha spicata (Labiatae) on iron absorption in rats. Toxicol. Ind. Health, 20(610):119-22, 2004a.

Akdogan, M.; Ozguner, M.; Kocak, A.; Oncu, M. \& Cicek, E. Effect of peppermint teas on plasma testosterone, follicle stimulating hormon and luteinizing hormone level and testicular tissue in rats. Urology., 64(2):394-8, 2004 b.

Akdogan, M.; Tamer, M. N.; Cüre, E.; Cüre, M. C.; Körog `lu, B. K. \& Delibas, N. Effect of spearmint (Mentha spicata Labiatae) teas on androgen levels in women with hirsutism. Phytother. Res., 21(5):444-7, 2007.

Asao, T.; Kuwano, H. \& Ide, M.; Hirayama, I.; Nakamura, J. I.; Fujita, K. I. \& Horiuti, R. Spasmolytic effect of peppermint oil in barium during double-contrast barium enema compared with Buscopan. Clin. Radiol., 58(4):301-5, 2003.
Atta, A. H. \& Alkofahi, A. Anti-nociceptive and antiinflammatory effects of some Jordanian medicinal plant extracts. J. Ethnopharmacol., 60(2):117-24, 1998.

Azuma, K.; Ito, H.; Ippoushi, K. \& Higashio, H. In vitro antibacterial activity of extracts from four Labiatae herbs against Helicobacter pylori and Streptococcus mutans. Bull. Nat. Inst. Veg. Tea Sci., 2:83-91, 2003.

Baser, K. H. C. Essential oils of Anatolian labiatae: a profile. Acta Hortic., 333:217-38, 1993.

Choi, W. I.; Lee, E. H.; Choi, B. R.; Park, H. M. \& Ahn, Y. J. Toxicity of plant essential oils to Trialeurodes vaporariorum (Homoptera: Aleyrodidae). J. Econ. Entomol., 96(5):1479-84, 2003.

Duarte, M. C.; Figueira, G. M.; Sartoratto, A.; Rehder, V. L. \& Delarmelina, C. Anti-Candida activity of Brazilian medicinal plants. J. Ethnopharmacol., 97(2):305-11, 2005. 
García-Olmo, D. C.; Riese, H. H.; Escribano, J.; Ontañón, J.; Fernandez, J. A.; Atiénzar, M. \& García-Olmo, D. Effects of long-term treatment of colon adenocarcinoma with crocin, a carotenoid from saffron (Crocus sativus): an experimental study in the rat. Nutr.Cancer, 35(2):120-6,1999.

Göbel, H.; Fresenius, J.; Heinze, A.; Dworschak, M. \& Soyka, D. Effectiveness of Oleum menthae piperitae and paracetamol in therapy of headache of the tension type. Nervenarzt., 67(8):672-81, 1996.

Göbel, H.; Schmidt, G.; Dworschak, M.; Stolze, H. \& Heuss, D. Essential plant oils and headache mechanisms. Phytomedicine, 2(2):93-102,1995.

Golalipour, M. J.; Gharravi, A. M.; Ghafari, S.; Afshar, M. \& Khori, V. Effects of crocus sativus on the fetal development of NMRI mice. Saudi Med. J., 29(2):30910, 2008.

Gordon, W. P.; Huitric, A. C.; Seth, C. L.; McClanahan, R. H. \& Nelson, S. D. The metabolism of the abortifacient terpene, (R)- (+)- pulegone, to a proximate toxin menthofuran. Drug Metab. Dispos., 15(5):589-94,1987.

Güney, M.; Oral, B.; Karahanli, N.; Mungan, T. \& Akdogan, M. The effect of Mentha spicata Labiatae on uterine tissue in rats. Toxicol. Ind. Health, 22(8):343-8, 2006.

Hepner, D. L.; Harnett, M.; Segal, S.; Camann, W.; Bader, A. M. \& Tsen, L. C. Herbal medicine use in parturients. Anesth. Analg., 94(3):690-3, 2002.

Hiki, N.; Kurosaka, H.; Tatsutomi, Y.; Shimoyama, S.; Tsuji, E.; Kojima, J.; Shimizu, N.; Ono, H.; Hirooka, T.; Noguchi, C.; Mafune, K. \& Kaminishi, M. Peppermint oil reduces gastric spasm during upper endoscopy: a randomized, double-blind, double-dummy controlled trial. Gastrointest. Endosc., 57(4):475-82, 2003.

Inoue, T.; Sugimoto, Y.; Masuda, H. \& Kamei, C. Effects of Peppermint (Mentha piperita L.) extracts on experimental allergic rhinitis in rats. Biol. Pharm. Bull., 24(1):92-5, 2001.

Inoue, T.; Sugimoto, Y.; Masuda, H. \& Kamei, C. Antiallergic effect of flavonoid glycosides obtained from Mentha piperita L. Biol. Pharm. Bull., 25(2):2569, 2002.

Juergens, U. R.; Stöber, M. \& Vetter, H. The antiinflammatory activity of L-menthol compared to mint oil in human monocytes in vitro: a novel perspective for its therapeutic use in inflammatory diseases. Eur. $J$. Med. Res., 3(12):539-45, 1998.

Kline, R. M.; Kline, J. J.; Di Palma, J. \& Barbero, G. J. Enteric-coated, $\mathrm{pH}$-dependent peppermint oil capsules for the treatment of irritable bowel syndrome in children. J. Pediatr., 138(1):125-8, 2001.

Lazutka, J. R.; Mierauskiene, J.; Slapsyte, G. \& Dedonyte, V. Genotoxicity of dill (Anethum graveoleus L.), peppermint (Mentha piperita L.) and pine (Pinus sylvestris L.) essential oil in human lymphocytes and drosophila melanogaster. Food Chem. Toxical., 39(5):485-92, 2001.

Madisch, A.; Melderis, H.; Mayr, G.; Sassin, I. \& Hotz, J. Commercially available herbal preparation and its modified dispense in patients with functional dyspepsia. Results of a double-blind, placebo-controlled, randomized multicenter trial. Z. Gastroenterol., 39(7):511-7, 2001.

Micklefield, G.; Jung, O.; Greving, I. \& May, B. Effects of intraduodenal application of peppermint oil (WS(R) 1340) and caraway oil (WS(R) 1520) on gastroduodenal motility in healthy volunteers. Phytother. Res., 17(2):135-40, 2003.

Minami, M.; Kita, M.; Nakaya, T.; Yamamoto, T.; Kuriyama, H. \& Imanishi, J. The inhibitory effect of essential oils on herpes simplex virus type- 1 replication in vitro. Microbiol. Immunol., 47(9):6814, 2003.

Romero-Jiménez, M. \& Campos-Sánchez, M. Genotoxicity and anti-genotoxicity of some traditional medicinal herbs. Mutat. Res., 585(1-2):147-55, 2005.

Rösch, W.; Vinson, B. \& Sassin, I. A randomised clinical trial comparing the efficacy of an herbal preparation STW 5 with the prokinetic drug cisapride in patients with dysmotility type of functional dyspepsia. $Z$. Gastroenterol., 40(6):401-8, 2002.

Ruiz del Castillo, M. L.; Santa-María, G.; Herraiz, M. \& Blanch, G. P. A comparative study of the ability of different techniques to extract menthol from Mentha piperita. J. Chromatogr. Sci., 41(7):385-9, 2003.

Samarth, R. M. \& Kumar, A. Radioprotection of Swiss albino mice by plant extract Mentha piperita (Linn.). $J$. Radiat. Res., 44(2):101-9, 2003. 
Samarth, R. M.; Panwar, M.; Kumar, M. \& Kumar, A. Protective effects of Mentha piperita Linn on benzo[a]pyrene-induced lung carcinogenicity and mutagenicity in Swiss albino mice. Mutagenesis, 21(1):61-6, 2006.

Samman, M. A.; Bowen, I. D.; Taiba, K.; Antonius, J. \& Hannan, M. A. Mint prevents shamma-induced carcinogenesis in hamster cheek pouch. Carcinogenesis, 19(10):1795-801, 1998.

Sampaio, F. J. Effects of peppermint teas on plasma testosterone, follicle-stimulating hormone, and luteinizing hormone levels and testicular tissue in rats. Int. Braz. J. Urol., 30(4):350-1, 2004.

Satsu, H.; Matsuda, T.; Toshimitsu, T.; Mori, A.; Mae, T.; Tsukagawa, M.; Kitahara, M. \& Shimizu, M. Regulation of interleukin- 8 secretion in human intestinal epithelial Caco-2 cells. Biofactors, 21(1-4):137-9, 2004.

Schuhmacher, A.; Reichling, J. \& Schnitzler, P. Virucidal effect of peppermint oil on the enveloped viruses herpes simplex virus type 1 and type 2 in vitro. Phytomedicine, 10(6-7):504-10, 2003.

Spindler, P. \& Madsen, C. Subchronic toxicity study of peppermint [Mentha piperita and Mentha arvensis] oil in rats. Toxicol. Lett., 62:215-20, 1992.

Starburck, J. Herbs for sleep and relaxation. Men's Health, 16:24-6, 2001.

Tampieri, M. P.; Galuppi, R.; Macchioni, F.; Carelle, M. S.; Falcioni, L.; Cioni, P. L. \& Morelli, I. The inhibition of Candida albicans by selected essential oils and their major components. Mycopathologia, 159(3):339-45, 2005.

Tate, S. Peppermint oil: a treatment for postoperative nausea. J. Adv. Nurs., 26(3):543-9, 1997.

Thorup, I.; Würtzen, G.; Carstensen, J. \& Olsen, P. Short term toxicity study in rats dosed with peppermint oil. Toxicol. Lett., 19(3):211-5, 1983.

Westfall, R. E. Use of anti-emetic herbs in pregnancy: women's choices and the question of safety and efficiency. Complement. Ther. Nurs. Midwifery, 10(1):30-6, 2004.

Xu, P.; Jia, W.; Bi, L.; Liu, X. \& Zhao, Y. Studies on components and quality of essential oil from Mentha piperita L. produced in China. Chem. Ind. Forest Prod., 23:43-5, 2003

Zargari, A. Medicinal plants. $6^{\text {th }}$ ed. Tehran, Tehran University of Medical Sciences,1996. pp.5-10.

Zhang, X. WHO Traditional Medicine Strategy 2002-2005. Geneva, World Health Organization, 2002.

Correspondence to:

Dr. Mohammad Jafar Golalipour

Gorgan Congenital Malformations Research Center

Department of Anatomical Sciences

Golestan University of Medical Sciences

Gorgan, P.O.

Box: 49175-1141

IRAN

Tel/Fax: +98 (171) 4425 165, 4425660

Email: mjgolalipour@yahoo.com

Received: 15-01-2011

Accepted: 03-06-2011 